\title{
PENERAPAN BIMBINGAN KONSELING PENDIDIKAN DALAM MEMBENTUK KEDISIPLINAN LAYANAN BIMBINGAN PENGEMBANGAN DIRI
}

\author{
Siti Haryuni \\ Yayasan Pendidikan Nusantara 1 Kudus, \\ Jawa Tengah, Indonesia. \\ sitiharyuni9@gmail.com
}

\begin{abstract}
Abstrak
Tujuan dari tulisan ini adalah untuk mengetahui peranan bimbingan konseling pendidikan dalam membentuk kedisiplinan. Kajian ini membahas tentang proses pembentukan lingkungan dan upaya orang dewasa untuk membantu mencapai disiplin pribadi. Anak-anak kasus untuk mengikuti aturan menjadi tugas norma dewasa untuk membantu mereka menyesuaikan dan mengikuti aturan. Disiplin milik aset anak dalam menghadapi tantangan hidup mandiri di fase berikutnya. Orang tua dan guru dapat bekerja sama untuk menciptakan lingkungan yang kondusif sehingga siswa dalam proses pendidikan dapat mengoptimalkan potensi daya untuk prestasi mereka, kemampuan untuk menangani masalah, dan tugas-tugas perkembangan anak. Pendidikan yang lengkap dalam keluarga, di sekolah dan masyarakat akan membuat anak-anak menjadi generasi penerus yang terus mengembangkan diri memenuhi tuntutan budaya dan masa depan menjawab. Hasil dari kajian ini menunjukkan bahwa peranan bimbingan konseling pendidikan dalam membentuk kedisiplinan meliputi menaati aturan, kesadaran diri, alat pendidikan, dan hukuman.
\end{abstract}

Kata kunci: disiplin, bimbingan , konseling, pengembangan 
Siti Haryuni

\section{Abstract}

THE APPLICATION OF EDUCATION COUNSELING GUIDANCE IN CREATING DISCIPLINE (Self Development Guidance Service). The aim of this study is to know the role of education counseling guidance in creating discipline. It is an environmental formation process and the efforts of adults in helping to achieve, personal discipline. Discipline becomes the children's asset in facing the independent life challenges in the next phase. Parents and teachers can work together to create a conducive environment so that students in the educational process can optimize the power potential for their achievement, the ability to deal with the problems, and child development tasks. Complete education in the family, at school and the community will make the children become the next generation who constantly develop themselves meet the demands of culture and answering future. The result of this study showed that the role of education conseling guidance in creating disciplines are obeying the rules, self-awareness, educational tools, and punishment.

Keywords: discipline, guidance and counselling, self-development

\section{A. Pendahuluan}

Pendidikan merupakan proses untuk meningkatkan harkat dan martabat manusia, sekaligus mengangkat manusia manusia dari ketertinggalan. Melalui pendidikan, selain diperoleh kepandaian berolah pikir, juga akan diperoleh wawasan baru yang kesemuanya akan membantu upaya manusia untuk meningkatkan kualitas hidupnya, baik sebagai pribadi yang dewasa maupun sebagai anak bangsa. Pembangunan masyarakat Indonesia bertujuan membangun manusia Indonesia seutuhnya. Manusia merupakan kekuatan utama pembangunan dan sekaligus tujuan pembangunan (Hamdani, 2012: 15). Karena kualitas sumber daya manusia (SDM) di suatu negara sangat ditentukan oleh pendidikan, karena pendidikan sangat erat kaitannya dengan pembentukan manusia seutuhnya berdasarkan Pancasila. Dalam pendidikan dimaksudkan pula untukmempersiapkan generasi penerus dengan sebaik-baiknya agar dapat melaksanakan tugasnya di masa yang akan datang. Dunia pendidikan adalah tempat anakanak menimba ilmu baik yang kognitif (matematika, fisika, kimia dan lain-lain), afektif (ilmu pengetahuan sosial, sosiologi dan lainlain), psikomotor (agama, budi pekerti, kedisiplinan, ketrampilan, pendidikan moral pancasila dan lain-lain). Ilmu yang mencakup ranah 
kognitif, afektif dan psikomotor adalah modal yang dimiliki siswa untuk menghadapi tantangan masa depan yang penuh persaingan. Sehingga program pemerintah untuk wajib belajar sembilan tahun merupakan cara untuk mengentaskan kebodohan yang merupakan sumber kemiskinan dan perasaan pesimis.

Dibutuhkannya pendidikan, karena menurut Ki Hadjar Dewantara bahwa anak adalah seperti kertas putih atau disebut dengan tabula rasa. Sesuai dengan Rasulullah saw. yang menjelaskan bahwa manusia dilahirkan dengan membawa fitrah dan agama yang lurus. Abu Hurairah meriwayatkan bahwa Rasulullah saw. Bersabda: "Semua anak dilahirkan dalam fitrah. Lantas kedua orang tuanya menjadikannya seorang Yahudi, Nasrani, atau Majusi. Sebagaimana halnya binatang melahirkan anak binatang secara sempurna, apakah kalian rasa terdapat cacat pada anak binatang itu?” Kemudian Abu Hurairah berkata, "Bacalah jika engkau mau: Itulah fitrah Allah yang berdasarkan fitrah itu Dia menciptakan manusia. Dalam hadis ini Rasulullah Saw. menjelaskan bahwa seorang anak dilahirkan dalam keadaan fitrah (memiliki kesiapan) untuk memeluk agama yang lurus. Hanya saja pada fase perkembangannya, anak tersebut akan sangat dipengaruhi oleh perilaku orang tuanya, faktor pendidikan dan lingkungan tempat anak-anak tumbuh. Kedua orang tualah yang membuat anak-anak menjadi penganut Yahudi, Nasrani, atau Majusi. Itulah yang menjadi pengaruh fitrah yang dibawanya sejak lahir menjadi lemah. Maka tumbuhlah anak-anak dalam agama yang diajarkan kedua orang tuanya (Najati, 2005: 32).

Pada dasarnya setiap orang harus menjadi pendidik, sesuai dengan kemampuannya masing-masing. Karena secara umum diketahui bahwa ada 3 macam pendidikan, yaitu pendidikan formal (sekolah), non-formal (lembaga latihan) dan informal (keluarga maupun masyarakat. Keberhasilan pendidikan tidak hanya dari segi kognitif, namun dari segi afektif dan psikomotor. Karena kesuksesan hidup seseorang karena keharmonisan/keseimbangan antara kecerdasan dalam berpikir, kemampuan mengontrol emosi dan kemampuan dalam menyesuaikan dengan diri sendiri maupun menyesuaikan dengan lingkungan. Meskipun di masyarakat pendidikan sering di jumpai hanya mengutamakan segi kognitif saja. Namun dengan bukti-bukti yang sudah ada (kesuksesan hidup 
ditentukan oleh kognitif, afektif dan psikomotor) dapat dijadikan acuan memberikan pendidikan kepada anak perlu memperhatikan aspek kognitif, afektif dan emosi secara seimbang.

Keseimbangan aspek kognitif, afektif dan psikomotor dalam pendidikan dibutuhkan adanya bantuan dalam bentuk bimbingan maupun konseling. Karena dalam kegiatan pendidikan atau belajar seringkali dijumpai masalah, problem, atau kesulitan, yang disebabkan oleh banyak faktor. Mengingat bahwa esensi pendidikan umum adalah proses menghadirkan situasi dan kondisi yang memungkinkan sebanyak mungkin subjek didik memperluas dan memperdalam makna-makna esensial untuk mencapai kehidupan yang manusiawi. Dalam hal ini, sangat diperlukan adanya kesengajaan atau kesadaran (niat) untuk mengundangnya melakukan tindak belajar yang sesuai dengan tujuan. Tujuan esensial pendidikan umum adalah mengupayakan subjek didik menjadi pribadi yang utuh dan terintegrasi. Pribadi yang memiliki dasar-dasar dan mampu mengembangkan disiplin diri, berarti memiliki keteraturan diri berdasarkan acuan nilai moral. Sehubungan dengan itu, disiplin diri di bangun dari asimilasi dan penggabungan nilai-nilai moral untuk diinternalisasi oleh subjek didik sebagai dasar-dasar untuk mengarahkan perilakunya. Dunia pendidikan dapat merealisasikannya dengan cara menciptakan situasi dan kondisi yang di hayati oleh anak-anak agar memiliki dasar-dasar dalam pembentukan dan pengembangan disiplin diri. Anak yang berdisiplin diri memiliki keteraturan diri berdasarkan nilai agama, nilai budaya, aturan-aturan pergaulan, pandangan hidup, dan sikap hidup yang bermakna bagi dirinya sendiri, masyarakat, bangsa dan negara (Shochib, 1998: 3). Sehingga upaya merealisasikan bimbingan konseling sesuai dengan kondisi anak sebagai sarana optimalisasi pengembangan diri anak menuju tahapan usia selanjutnya.

\section{B. Pembahasan}

Perkembangan sekarang ini, masyarakat lebih mengenal dengan bimbingan konseling sebagai cara untuk memberi bantuan. Arti dari bimbingan adalah sebagai suatu proses pemberian bantuan kepada individu yang dilakukan secara berkesinambungan supaya individu tersebut dapat memahami diri sendiri, sehingga dia sanggup mengarahkan dirinya dan dapat bertindak secara wajar, sesuai 
dengan tuntutan dan keadaan lingkungan sekolah, keluarga dan masyarakat serta kehidupan pada umumnya. Dengan demikian dia dapat menikmati kebahagaiaan hidupnya dan dapat memberikan sumbangan yang berarti dalam kehidupan masyarakat pada umunya. Bimbingan membantu individu mencapai perkembangan diri secara optimal sebagai makhluk sosial. Dan konseling adalah upaya bantuan yang diberikan kepada konseli supaya memperoleh konsep diri dan kepercayaan diri sendiri, untuk dimanfaatkan olehnya dalam memperbaiki tingkah lakunya pada masa yang akan datang. Dalam pembentukan konsep yang sewajarnya mengenai: diri sendiri, orang lain, pendapat orang lain tentang dirinya, tujuantujuan yang hendak dicapai dan kepercayaan (Sukardi, 2000: 21).

Pelayanan bimbingan dan konseling di Indonesia telah dirintis sejak tahun 1960-an. Mulai tahun 1975, pelayanan bimbingan dan konseling resmi memasuko sekolah-sekolah, yaitu dengan dicantumkannya pelayanan BK pada kurikulum 1975. Beberapa pasal dalam peraturan pemerintah yang bertalian dengan UUSPN 1989 secara eksplisit menyebutkan pelayanan bimbingan di sekolah dan memberikan kedudukan sebagai tenaga pendidik kepada petugas bimbingan (Hamdani, 2012: 97). Karena pendidikan adalah upaya mengarahkan perkembangan kepribadian (aspek psikologik dan psikofisik) manusia sesuai dengan hakekatnya agar menjadi insan kamil, dalam rangka mencapai tujuan akhir kehidupannya, yaitu kebahagiaan dunia akhirat. Tujuan pendidikan merupakan tujuan perantara hidup, dengan mencapai tujuan pendidikan diharapkan manusia kemudian bisa mencapai tujuan hidupnya. Tujuan hidup manusia sendiri, menurut hakekatnya adalah mencapai kebahagiaan dunia akhirat.

Istilah bimbingan pendidikan tampak seperti istilah yang tumpang tindih, sebab bimbingan itu juga pendidikan. Istilah tersebut sebenarnya sekedar kependekan dari bimbingan di bidang pendidikan. Dengan demikian maka yang dimaksud dengan bimbingan dan konseling pendidikan adalah kegiatan atau proses bimbingan dan konseling yang diberikan kepada individu dalam kegiatan belajar atau pendidikannya. Sehingga dapat diartikan bahwa bimbingan pendidikan adalah proses pemberian bantuan terhadap individu agar kegiatan belajar atau pendidikannya senantiasa selaras 
dengan tujuan pendidikan. Artinya penekanan bimbingan pendidikan adalah preventif, yaitu mencegah munculnya problem dalam kegiatan pendidikan seseorang dengan senantiasa memelihara kondisi yang baik agar tetap atau lebih baik. Dan konseling pendidikan adalah proses pemberian bantuan terhadap individu agar mampu mengatasi segala hambatan dalam kegiatan belajar atau pendidikannya.

Keberhasilan pendidikan dipengaruhi oleh berbagai faktor, antara lain:

\section{Faktor dari dalam}

1. Kecerdasan, yaitu kemampuan untuk memahami dan menghadapi situasi dan kondisi sekitar dengan cepat atau biasa di sebut "pintar".

2. Bakat, yaitu potensi atau kemampuan terpendam yang sangat menonjol di dalam bidang tertentu (misalnya: dalam bidang olah raga, seni, keilmuan dan sebagainya).

3. Minat, yaitu keinginan, kemauan, kehendak atau hasrat yang kuat terhadap sesuatu.

4. Perhatian, yaitu dorongan untuk mencurahkan daya kemampuan pengamatan (observasi) dengan panca indera terhadap sesuatu.

5. Keadaan mental (psikis), yaitu keadaan senang, sedih, gembira, duka, gelisah, frustasi, emosi, dan sebagainya.

6. Keadaan fisik, yaitu dalam keadaan sehat ataukah sakit.

\section{Faktor dari luar individu yang belajar}

1. Bahan/materi yang dipelajari, yaitu faktor mudah sulitnya bahan/materi tersebut untuk dipelajari seseorang.

2. Situasi dan kondisi lingkungan fisik, yaitu apakah lingkungan fisik tempat melakukan kegiatan belajar/pendidikan itu baik ataukah tidak (mencakup: ruang belajar, fasilitas belajar, suhu/iklim, suara, cahaya dan sebagainya).

3. Situasi dan kondisi lingkungan sosial, yaitu apakah lingkungan masyarakat tempat seseorang melakukan kegiatan belajar/ pendidikan itu kondusif, mendukung keberhasilan belajarnya atau tidak (mencakup: hubungan antar pendidik dengan peserta didik, hubungan antar sesama peserta didik, hubungan 
sekolah atau pendidik dengan masyarakat atau orang tua peserta didik dan masyarakat umum).

4. Sistem pengajaran/pendidikan, yaitu: bagaimana kegiatan pendidikan/belajar berlangsung, artinya strategi/metode belajar mengajar yang digunakan tepat atau tidak, intensitas belajar mengajar tinggi atau rendah, dan sebagainya.

Ketidakberhasilan seseorang dalam belajar atau tidak berhasil mencapai tujuan pendidikan, misalnya:

1. Individu tidak terampil mengerjakan suatu yang seharusnya bisa dilakukannya setelah mempelajarinya.

2. Individu tidak juga bisa memahami pokok bahasan (materi pelajaran) tertentu kendati telah dicoba mempelajarinya sekuat tenaga.

3. Individu segan atau malas untuk mempelajari bahan pelajaran tertentu.

4. Individu sulit menyelesaikan tugas-tugas sekolah karena di rumah terlampau banyak pekerjaan yang harus diselesaikan.

5. Individu berkali-kali gagal menguasai bahan pelajaran yang harus dipelajarinya sesuai dengan target yang seharusnya.

Petunjuk pelaksanaan bimbingan dan bimbingan dan konseling, Kurikulum Sekolah Menengah Umum 1994, dikatakan sebagai berikut: Berdasarkan Pasal 27 Peraturan Pemerintah Nomor 29 1992, bimbingan merupakan bantuan yang diberikan kepada siswa dalam rangka menemukan pribadi, mengenal lingkungan dan merencanakan masa depan (Hamdani, 2012: 97). Sehingga bimbingan dan konseling merupakan salah satu komponen pendidikan, mengingat bahwa bimbingan dan konseling adalah merupakan suatu kegiatan bantuan dan tuntunan yang diberikan kepada individu pada umunya, dan siswa pada khususnya di sekolah dalam rangka meningkatkan mutunya. Hal ini sangat relevan jika dilihat dari perumusan bahwa pendidikan itu adalah merupakan usaha sadar yang bertujuan untuk mengembangakan kepribadian dan potensi-potensinya (bakat minat, dan kemampuannya). Kepribadian menyangkut masalah perilaku atau sikap mental dan kemampuan meliputi masalah akademik dan keterampilan (Sukardi, 2000: 1). Kepribadian yang baik merupakan salah satu tujuan dari pendidikan 
dan akan terwujud jika ada kedisiplinan. Hal ini merupakan bukti bahwa penerapan bimbingan konseling pendidikan dapat membentuk kedisiplinan siswa.

Istilah disiplin berasal dari bahasa Latin "disciplina” yang menunjuk kepada kegiatan belajar dan mengajar. Istilah tersebut sangat dekat dengan istilah dalam bahasa Inggris "disciple" yang berarti mengikuti orang untuk belajar di bawah pengawasan seorang pemimpin. Istilah bahasa Inggris lainnya, yakni discipline, berarti (1) tertib, taat, atau mengendalikan tingkah laku, penguasaan diri, kendali diri, (2) latihan membentuk, meluruskan, atau menyempurnakan sesuatu, sebagai kemampuan mental atau karakter moral, (3) hukuman yang diberikan untuk melatih atau memperbaiki, (4) kumpulan atau sistem peraturan-peraturan bagi tingkah laku. Dalam bahasa Indonesia istilah disiplin kerapkali terkait dan menyatu dengan istilah tata tertib dan ketertiban. Bahkan, disiplin itu sesuatu yang menjadi bagian dalam hidup seseorang, yang muncul dalam pola tingkah lakunya sehari-hari. Disiplin terjadi dan terbentuk sebagai hasil dan dampak proses pembinaan cukup panjang yang dilakukan sejak dari dalam keluarga dan berlanjut dalam pendidikan di sekolah. Keluarga dan sekolah menjadi tempat penting bagi pengembangan disiplin seseorang.

Tim Kelompok Kerja Gerakan Disiplin Nasional 1995, merumuskan pengertian disiplin, sebagai berikut: Disiplin sebagai ketaatan terhadap peraturan dan norma kehidupan masyarakat, berbangsa dan bernegara yang berlaku, yang dilaksanakan secara sadar dan ikhlas lahir batin, sehingga timbul rasa malu terkena sanksi dan rasa takut terhadap Tuhan Yang Maha Esa. Perilaku tersebut diikuti berdasarkan keyakinan bahwa hal itulah yang benar, dan keinsyafan bahwa hal itu bermanfaat bagi dirinya dan masyarakat. Pada sisi lain, disiplin adalah alat untuk menciptakan perilaku dan tata tertib manusia sebagai pribadi maupun sebagai kelompok masyarakat. Oleh sebab itu, disiplin di sini berarti hukuman atau sanksi yang berbobot mengatur dan mengendalikan perilaku.

Rumusan tersebut menekankan disiplin sebagai alat dan sarana untuk membentuk, mengendalikan dan menciptakan pola perilaku seseorang sebagai pribadi yang berada dalam satu lingkungan atau kelompok tertentu. Disiplin muncul terutama karena adanya 
kesadaran batin dan iman kepercayaan bahwa yang dilakukan itu baik dan bermanfaat bagi diri dan lingkungan. Rachman (1999:168) dalam buku Manajemen Kelas, mengartikan disiplin sebagai upaya mengendalikan diri dan sikap mental individu atau masyarakat dalam mengembangkan kepatuhan dan ketaatan terhadap peraturan dan tata tertib berdasarkan dorongan dan kesadaran yang muncul dari dalam dirinya.

Bohar Soeharto dalam Tu’u (2004:32) menyebutkan tiga hal mengenai disiplin, yaitu:

1. Disiplin sebagai latihan untuk menuruti kemauan seseorang. Jika dikatakan "melatih untuk menurut" berarti jika seseorang memberi perintah, orang lain akan menuruti perintah itu.

2. Disiplin sebagai hukuman. Bila seseorang berbuat salah, harus dihukum. Hukuman itu sebagai upaya mengeluarkan yang jelek dari dalam diri orang itu sehingga menjadi baik.

3. Disiplin sebagai alat untuk mendidik. Seorang anak memiliki potensi untuk berkembang melalui interaksi dengan lingkungan untuk mencapai tujuan realisasi dirinya. Dalam interaksi tersebut anak belajar tentang nilai-nilai sesuatu. Proses belajar dengan lingkungan yang di dalamnya terdapat nilai-nilai tertentu telah membawa pengaruh dan perubahan perilakunya. Perilaku ini berubah tertuju pada arah yang sudah ditentukan oleh nilai-nilai yang dipelajari. Jadi, fungsi belajar adalah mempengaruhi dan mengubah perilaku seorang anak. Semua perilaku merupakan hasil sebuah proses belajar. Inilah sebetulnya makna disiplin. Dalam pemahaman yang ketiga inilah seharusnya disiplin dikembangkan.

Berdasarkan rumusan dan pendapat tersebut, maka rumusan disiplin sebagai berikut: (1) Mengikuti dan menaati peraturan, nilai, dan hukum yang berlaku, (2) Pengikutan dan ketaatan tersebut terutama muncul karena adanya kesadaran diri bahwa hal itu berguna bagi kebaikan dan keberhasilan dirinya. Dapat juga muncul karena rasa takut, tekanan, paksaan dan dorongan dari luar dirinya, (3) Sebagai alat pendidikan untuk mempengaruhi, mengubah, membina dan membentuk perilaku sesuai dengan nilai-nilai yang ditentukan atau diajarkan, (4) Hukuman yang diberikan bagi yang 
melanggar ketentuan yang berlaku, dalam rangka mendidik, melatih, mengendalikan dan memperbaiki tingkah laku, (5) Peraturanperaturan yang berlaku sebagai pedoman dan ukuran perilaku.

Disiplin diperlukan oleh siapa pun dan di mana pun. Hal itu disebabkan di manapun seseorang berada, di sana selalu ada peraturan atau tata tertib. Soegeng Prijodarminto mengatakan: di jalan, di kantor, di toko swalayan, di rumah sakit, di stasiun, naik bus, naik lift, dan sebagainya, diperlukan ada ketertiban dan keteraturan. Jadi, manusia mustahil hidup tanpa disiplin. Manusia memerlukan disiplin dalam hidupnya di mana pun berada. Apabila manusia mengabaikan disiplin, akan menghadapi banyak masalah dalam kehidupan seharihari. Oleh karena itu, perilaku hidupnya tidak sesuai dengan peraturan yang berlaku di tempat manusia berada dan yang menjadi harapan.

Selanjutnya dikatakan juga, para pendidik, orang tua dan guru, sebagaimana halnya dengan pemimpin kelompok, melihat disiplin ini sebagai sesuatu yang sangat penting dalam interaksi manusia. Dalam kerangka pembangunan dan kemajuan bangsa dan negara, disiplin sangat penting dan menentukan. Karena kemajuan pembangunan, martabat dan kesejahteraan bangsa tercapai karena warga masyarakatnya memiliki disiplin yang baik.

Disiplin sekolah apabila dikembangkan dan diterapkan dengan baik, konsisten dan konsekuen akan berdampak positif bagi kehidupan dan perilaku siswa. Disiplin dapat mendorong mereka belajar secara konkret dalam praktik hidup di sekolah tentang halhal positif: melakukan hal-hal yang lurus dan benar, menjauhi halhal negatif. Dengan pemberlakuan disiplin, siswa belajar beradaptasi dengan lingkungan yang baik itu, sehingga muncul keseimbangan diri dalam hubungan dengan orang yang lain. Jadi, disiplin menata perilaku seseorang dalam hubungannya di tengah-tengah lingkungannya.

Dalam hal itu, menurut Maman Rachman sebagaimana dikutip oleh Tu'u (2004: 35) pentingnya disiplin bagi para siswa sebagai berikut:

1. Memberi dukungan bagi terciptanya perilaku yang tidak menyimpang.

2. Membantu siswa memahami dan menyesuaikan diri dengan tuntutan lingkungan. 
3. Cara menyelesaikan tuntutan yang ingin ditunjukkan peserta didik terhadap lingkungannya.

4. Untuk mengatur keseimbangan keinginan individu satu dengan individu lainnya.

5. Menjauhi siswa melakukan hal-hal yang dilarang sekolah.

6. Mendorong siswa melakukan hal-hal yang baik dan benar.

7. Peserta didik belajar hidup dengan kebiasaan-kebiasaan yang baik, positif dan bermanfaat baginya dan lingkungannya.

8. Kebiasaan baik itu menyebabkan ketenangan jiwanya dan lingkungannya.

Lingkungan sekolah yang teratur, tertib, tenang tersebut memberi gambaran lingkungan siswa yang giat, gigih, serius, penuh perhatian, sungguh-sungguh dan kompetitif dalam kegiatan pembelajarannya. Lingkungan disiplin seperti itu ikut memberi andil lahirnya siswa-siswa yang berprestasi dengan kepribadian unggul. Di sana ada dan terjadi kompetisi positif di antara mereka.

Pendidikan kecakapan hidup yang memiliki otoritas dibidang pendidikan, pelatihan dan kesehatan. Menurut Broling bahwa life skill adalah interaksi berbagai pengetahuan dan kecakapan yang sangat penting dimiliki oleh seseorang sehingga dapat hidup mandiri (Retnanto, 2009: 228) dengan ciri-ciri keunggulan individu. Wardiman Djojonegoro (1996: 261)mengatakan individu unggul memiliki ciri-ciri sebagai berikut:

1. Motivasi berpikir dan berkarya yang berorientasi pada prestasi unggul.

2. Motivasi dalam mengembangkan bakat dan potensi dirinya untuk mencapai keunggulan.

3. Daya saing sekaligus daya kerja sama yang tinggi.

4. Daya nalar yang tinggi serta matang dan berkesinambungan.

5. Kemampuan berprakarsa.

6. Kemampuan untuk memperhitungkan resiko.

7. Sikap pencapaian prestasi dalam rangka persaingan.

Untuk mencapai dan memiliki ciri-ciri kepribadian unggul tersebut, diperlukan pribadi yang gigih, tekun dan disiplin. Selanjutnya Wardiman mengatakan: Keunggulan tersebut baru dapat dimiliki apabila dalam diri seseorang terdapat sikap dan 
perilaku disiplin. Disiplin inilah yang dapat mendorong adanya motivasi, daya saing, kemampuan dan sikap yang melahirkan ketujuh keunggulan tersebut.

Jadi, disiplin berperan penting dalam membentuk individu yang berciri keunggulan. Berdasarkan pengalaman Tu'u, disiplin itu penting karena alasan berikut ini:

1. Dengan disiplin yang muncul karena kesadaran diri, siswa berhasil dalam belajarnya. Sebaliknya siswa yang kerap kali melanggar ketentuan sekolah pada umunya terhambat optimalisasi potensi dan prestasinya.

2. Tanpa disiplin yang baik, suasana sekolah dan juga kelas, menjadi kurang kondusif bagi kegiatan pembelajaran. Secara positif, disiplin memberi dukungan lingkungan yang tenang dan tertib bagi proses pembelajaran.

3. Orangtua senantiasa berharap di sekolah anak-anak dibiasakan dengan norma-norma, nilai kehidupan dan disiplin. Dengan demikian, anak-anak dapat menjadi individu yang tertib, teratur dan disiplin.

4. Disiplin merupakan jalan bagi siswa untuk sukses dalam belajar dan kelak ketika bekerja. Kesadaran pentingnya norma, aturan, kepatuhan dan ketaatan merupakan prasyarat kesuksesan seseorang.

Mengikuti pendapat Albert Einstein, mengatakan bahwa keberhasilan seseorang ditentukan oleh 90\% kegigihan dan kerja keras, sedangkan $10 \%$ oleh kecerdasannya. Sementara Martina Sudibja mengatakan: Keberhasilan seseorang dalam bekerja, setelah menyelesaikan studinya, ditentukan $80 \%$ oleh sikap dan ketrampilannya, sedangkan pengetahuannya memberi kontribusi hanya sebesar 20\% (Tu'u, 2004: 37).

Disiplin sangat penting dan dibutuhkan oleh setiap siswa. Disiplin menjadi prasyarat bagi pembentukan sikap, perilaku dan tata kehidupan berdisiplin, yang akan mengantar seorang siswa sukses dalam belajar dan kelak ketika bekerja. Beberapa fungsi disiplin, yaitu:

\section{Menata kehidupan bersama}

Manusia adalah makhluk unik yang memiliki ciri, sifat, 
kepribadian, latar belakang dan pola pikir yang berbeda-beda. Selain sebagai satu individu, juga sebagai makhluk sosial. Sebagai makhluk sosial, selalu terkait dan berhubungan dengan orang lain.

Dalam hubungan tersebut, diperlukan norma, nilai, peraturan untuk mengatur agar kehidupan dan kegiatannya dapat berjalan baik dan lancar. Kepentingan individu yang satu tidak berbenturan dengan kepentingan individu lain. Disiplin berguna untuk menyadarkan seseorang bahwa dirinya perlu menghargai orang lain dengan cara menaati dan mematuhi peraturan yang berlaku. Ketaatan dan kepatuhan itu membatasi dirinya merugikan pihak lain, tetapi hubungan dengan sesama menjadi baik dan lancar. Jadi fungsi disiplin adalah mengatur tata kehidupan manusia, dalam kelompok tertentu atau dalam masyarakat. Dengan begitu, hubungan antara individu satu dengan yang lain menjadi baik dan lancar.

\section{Membangun kepribadian}

Kepribadian adalah keseluruhan sifat, tingkah laku dan pola hidup seseorang yang tercermin dalam penampilan, perkataan dan perbuatan sehari-hari. Sifat, tingkah laku dan pola hidup tersebut sangat unik sehingga membedakan dirinya dengan orang lain. Pertumbuhan kepribadian seseorang biasanya dipengaruhi oleh faktor lingkungan keluarga, lingkungan pergaulan, lingkungan masyarakat, lingkungan sekolah. Disiplin yang diterapkan di masing-masing lingkungan tersebut memberi dampak bagi pertumbuhan kepribadian yang baik. Oleh karena itu, dengan disiplin, seseorang dibiasakan mengikuti, mematuhi, menaati aturan-aturan yang berlaku. Kebiasaan itu, lama kelamaan masuk ke dalam dirinya sehingga akhirnya menjadi milik kepribadiannya. Disiplin telah menjadi bagian dalam kehidupannya sehari-hari.

Berkaitan dengan hal tersebut, Wardiman Djojonegoro sebagaimana dikutip oleh Tu'u (2004:19) mengatakan: Penerapan disiplin yang mantap dalam kehidupan sehari-hari berawal dari disiplin pribadi. Disiplin pribadi dipengaruhi dari dua faktor, yakni faktor dari dalam dan faktor dari luar. Faktor dari luar berupa lingkungan, sedangkan faktor dalam berupa kesadaran diri. Jadi lingkungan yang berdisiplin baik, sangat berpengaruh terhadap kepribadian seseorang. Apalagi seorang siswa yang sedang tumbuh kepribadiannya, tentu 
lingkungan sekolah yang tertib, teratur, tenang, tenteram, sangat berperan dalam membangun kepribadian yang baik.

\section{Melatih kepribadian}

Sikap, perilaku dan pola kehidupan yang baik dan berdisiplin tidak terbentuk serta merta dalam waktu singkat. Namun, terbentuk melalui satu proses yang membutuhkan waktu panjang. Salah satu proses untuk membentuk kepribadian tersebut dilakukan melalui latihan.

Latihan adalah belajar dan berbuat serta membiasakan diri melakukan sesuatu secara berulang-ulang. Dengan cara itu, orang menjadi terbiasa, terlatih, terampil dan mampu melakukan sesuatu dengan baik (dalam Kamus Bahasa Indonesia).

Demikian juga dengan kepribadian yang tertib, teratur, taat, patuh, perlu dibiasakan dan dilatih. Pola hidup seperti itu mustahil dapat terbentuk begitu saja. Hal itu memerlukan waktu dan proses yang memakan waktu. Perlu adanya latihan, pembiasaan diri, mencoba, berusaha dengan gigih, bahkan dengan gemblengan dan tempaan keras.Melalui tempaan manusia akan menjadi kuat. Melalui tempaan mental dan moral seorang akan teruji, melalui tempaan pula menjadikan seorang dapat mengatasi masalah-masalah yang dihadapi dengan penuh ketabahan dan kegigihan. Melaui tempaan pula mereka memperoleh nilai tambah. Disiplin tersebut akan terwujud melalui pembinaan sejak dini, sejak usia muda, dimulai dari lingkungan keluarga, melalui pendidikan yang tertanam sejak usia muda yang semakin lama semakin menyatu kuat dalam dirinya dengan bertambahnya usia.

\section{Pemaksaan}

Dalam materi "Latihan Kepemimpinan Siswa SLTA/SLTP SeKodya Bandung, tahun 1995”, pengertian disiplin dapat dirangkum sebagai berikut. Disiplin adalah sikap mental yang mengandung kerelaan mematuhi semua ketentuan, peraturan dan norma yang berlaku dalam menunaikan tugas dan tanggung jawab. Faktor yang mendorong terbentuknya kedisiplinan, yaitu dorongan dari dalam (terdiri dari pengalaman, kesadaran, dan kemauan untuk berbuat disiplin) dan dorongan dari luar (perintah, larangan, pengawasan, pujian, ancaman, ganjaran). 
Dari pendapat itu, disiplin dapat terjadi karena dorongan kesadaran diri. Disiplin dengan motif kesadaran diri ini lebih baik dan kuat. Dengan melakukan kepatuhan dan ketaatan atas kesadaran diri, bermanfaat bagi kebaikan dan kemajuan diri. Sebaliknya, disiplin dapat pula terjadi karena adanya pemaksaan dan tekanan dari luar. Misalnya, ketika seorang siswa yang kurang disiplin masuk ke satu sekolah yang berdisiplin baik, terpaksa harus menaati dan mematuhi tata tertib yang ada di sekolah tersebut. Dikatakan terpaksa, karena melakukan bukan berdasarkan kesadaran diri, melainkan karena rasa takut dan ancaman sanksi disiplin. Disiplin yang terpaksa, bukan karena kesadaran diri, akan memberi pengaruh kurang baik. Anak akan stres, merasa kurang bebas dan mandiri, terpaksa, dan hanya memenuhi keinginan pihak lain. Dalam hal seperti itu, Soegeng Prijodarminto sebagaimana dikutip oleh Tu'u (2004: 41) mengatakan: disiplin yang terwujud karena adanya paksaan atau tekanan dari luar akan cepat pudar kembali bilamana faktor-faktor luar tersebut lenyap.

Jadi, disiplin dapat berfungsi sebagai pemaksaan kepada seseorang untuk mengikuti peraturan-peraturan yang berlaku di lingkungan itu. Memang disiplin seperti ini masih dangkal. Akan tetapi, dengan pendampingan guru-guru, pemaksaan, pembiasaan dan latihan disiplin seperti itu dapat menyadarkan siswa bahwa disiplin itu penting baginya. Dari mula-mula karena paksaan, kini dilakukan karena kesadaran diri, menyentuh kalbunya, merasakan sebagai kebutuhan dan kebiasaan. Diharapkan juga, disiplin ini meningkat menjadi kebiasaan berpikir baik, positif, bermakna, memandang jauh ke depan. Disiplin bukan hanya soal mengikuti dan menaati aturan, melainkan sudah meningkat menjadi disiplin berpikir yang mengatur dan mempengaruhi seluruh aspek hidupnya.

\section{Hukuman}

Tata tertib sekolah biasanya berisi hal-hal positif yang harus dilakukan oleh siswa. Sisi lainnya berisi sanksi atau hukuman bagi yang melanggar tata tertib tersebut. Ancaman sanksi sangat penting karena dapat memberi dorongan dan kekuatan bagi siswa untuk menaati dan mematuhinya. Tanpa ancaman hukuman/sanksi, dorongan ketaatan dan kepatuhan dapat diperlemah. Motivasi untuk hidup mengikuti aturan yang berlaku menjadi lemah. 
Siti Haryuni

Tata tertib yang sudah disusun dan disosialisakan seharusnya diikuti dengan penerapan secara konsisten dan konsekuen. Siswa yang melanggar peraturan yang berlaku harus diberi sanksi disiplin. Tanpa sanksi disiplin/hukuman yang konsisten dan konsekuen akan membingungkan, memunculkan ketidakpuasan dan rasa ketidakadilan bagi yang disiplin.

Beberapa definisi hukuman telah dikemukakan oleh beberapa ahli, di antaranya:

1. Hukuman adalah tindakan yang dijatuhkan kepada anak secara sadar dan sengaja sehingga menimbulkan nestapa, dan dengan adanya nestapa itu anak akan menjadi sadar akan perbuatannya dan berjanji di dalam hatinya untuk tidak mengulanginya (Indrakusuma, 1973: 14).

2. Menghukum adalah memberikan atau mengadakan nestapa/ penderitaan dengan sengaja kepada anak yang menjadi asuhan kita dengan maksud supaya penderitaan itu betul-betul dirasainya untuk menuju kearah perbaikan. (Suwarno, 1981: 115).

Jenis atau bentuk hukuman yang dijatuhkan berbagai macam, Hasibuan (1988:56-61) mengungkapkan tentang bentuk dari hukuman tersebut. Bentuk-bentuk hukuman lebih kurang dapat dikelompokan menjadi empat kelompok, yaitu:

1. hukuman fisik, misalnya: dengan mencubit, menampar, memukul dan lain sebagainya;

2. hukuman dengan kata-kata atau kalimat yang tidak menyenangkan, seperti omelan, ancaman, kritikan, sindiran, cemoohan dan lain sejenisnya;

3. hukuman dengan stimulus fisik yang tidak menyenangkan, misalnya menuding, memelototi, mencemberuti dan lain sebagainya;

4. hukuman dalam bentuk kegiatan yang tidak menyenangkan, misalnya disuruh berdiri di depan kelas, dikeluarkan dari dalam kelas, didudukan di samping guru, disuruh menulis suatu kalimat sebanyak puluhan atau ratusan kali, dan lain sebagainya.

Sanksi itu diharapkan mempunyai nilai pendidikan. Artinya, siswa menyadari bahwa perbuatan yang salah akan membawa akibat 
yang tidak menyenangkan dan harus ditanggung olehnya. Dengan demikian, diharapkan tidak ada lagi pelanggaraan yang sama atau yang lain. Siswa lain pun menjadi takut melakukan pelanggaran, karena sekolah akan menerapkan sanksi disiplin secara konsisten.

Menurut Wijanarko (2005: 5) hukuman berfungsi sebagai alat untuk menegaskan peraturan, menyatakan kesalahan, dan menyadarkan seseorang yang berada di jalan yang salah agar meninggalkan jalan tersebut. Di samping itu, hukuman juga berguna bagi seseorang yang sedang belajar untuk mau diatur dan mau menundukkan diri di bawah kepemimpinan/otoritas orang lain. Karena itu, sanksi disiplin berupa hukuman tidak boleh dilihat hanya sebagai cara untuk menakut-nakuti atau untuk mengancam supaya orang tidak berani berbuat salah. Sanksi seharusnya sebagai alat pendidikan dan mengandung unsur pendidikan. Tanpa unsur itu, hukuman kurang bermanfaat.

Dalam hal ini, hukuman yang dilakukan untuk menakutnakuti hampir tidak ada gunanya dan akan menimbulkan kesulitan. Hukuman akan membuat seseorang merasa terpojok dan frustrasi. Frustrasi sering diikuti oleh agresi dan dengan agresi merasa telah mendapatkan atau memperbaiki status kembali.

\section{Mencipta lingkungan kondusif}

Sekolah merupakan ruang lingkup pendidikan (Wawasan Wiyatamandala). Dalam pendidikan ada proses mendidik, mengajar dan melatih. Mendidik mengarah kepada meningkatkan moral, mental, spiritual dan kepribadian. Mengajar atau pembelajaran meningkatkan kemampuan berpikir yang mengarah kepada peningkatan keterampilan.

Sekolah sebagai ruang lingkup pendidikan perlu menjamin terselenggaranya proses pendidikan yang baik. Kondisi yang baik bagi proses tersebut adalah kondisi aman, tenteram, tenang, tertib dan teratur, saling mnenghargai, dan hubungan pergaulan yang baik. Apabila kondisi tersebut terwujud, sekolah akan menjadi lingkungan kondusif bagi kegiatan dan proses pendidikan. Di tempat seperti itu, potensi dan prestasi siswa akan mencapai hasil optimal. Sebab, unsur-unsur yang menghambat proses pendidikan dapat diatasi dan diminimalkan oleh situasi kondusif tersebut. 
Disiplin sekolah berfungsi mendukung terlaksananya proses dan kegiatan pendidikan agar berjalan lancar. Hal itu di capai dengan merancang peraturan sekolah, yakni peraturan bagi guru-guru, dan bagi para siswa, serta peraturan-peraturan lain yang dianggap perlu. Kemudian di implementasikan secara konsisten dan konsekuen. Dengan demikian, sekolah menjadi lingkungan pendidikan yang aman, tenang, tenteram, tertib dan teratur. Lingkungan seperti ini adalah lingkungan yang kondusif bagi pendidikan. Jadi peraturan sekolah yang dirancang dan diimplementasikan dengan baik, memberi pengaruh bagi terciptanya sekolah sebagai lingkungan pendidikan yang kondusif bagi kegiatan pembelajaran. Tanpa ketertiban, suasana kondusif bagi pembelajaran akan terganggu. Prestasi belajar pun ikut terganggu (Tu’u, 2004: 44). Macam-macam disiplin:

\section{Disiplin Otoritarian}

Dalam disiplin otoritarian, peraturan dibuat sangat ketat dan rinci. Apabila gagal menaati dan mematuhi peraturan yang berlaku, akan menerima sanksi atau hukuman berat. Sebaliknya, bila berhasil memenuhi peraturan, kurang mendapat penghargaan atau hal itu sudah dianggap sebagai kewajiban. Jadi, tidak perlu mendapat penghargaan lagi.

Disiplin otoritarian selalu berarti pengendalian tingkah laku berdasarkan tekanan, dorongan, pemaksaan dari luar diri seseorang. Hukuman dan ancaman kerapkali dipakai untuk memaksa, menekan, mendorong seseorang mematuhi dan menaati peraturan. Di sini, tidak diberi kesempatan bertanya mengapa disiplin itu harus dilakukan dan apa tujuan disiplin itu. Orang hanya berpikir kalau harus dan wajib mematuhi dan menaati peraturan yang berlaku. Kepatuhan dan ketaatan dianggap baik dan perlu bagi diri, institusi atau keluarga. Apabila disiplin dilanggar, wibawa dan otoritas institusi atau keluarga menjadi terganggu. Karena itu, setiap pelanggaran perlu diberi sanksi, ada sesuatu yang harus ditanggung sebagai akibat pelanggarannya. Di sini dapat terjadi orang patuh dan taat pada aturan yang berlaku, tetapi merasa tidak bahagia, tertekan dan tidak aman. Siswa kelihatan baik, tetapi dibaliknya ada ketidakpuasan, pemberontakan dan kegelisahan. Dapat juga menjadi stres: karena tampak baik, patuh, taat, tetapi merasa kurang bebas, kurang mandiri, berbuat sesuatu hanya sekadar untuk memuaskan pihak lain (orang tua, sekolah, guru, atasan). 
Sebenarnya, semua perbuatannya hanya karena keterpaksaan dan ketakutan menerima sanksi. Bukan berdasarkan kesadaran diri. Hal seperti ini, bila memang terjadi, tentu kurang menggembirakan. Di sini mereka perlu dibantu untuk memahami arti dan manfaat disiplin itu bagi dirinya, agar ada kesadaran diri yang baik tentang disiplin.

2. Disiplin Permisif

Dalam disiplin ini seseorang dibiarkan bertindak menurut keinginannya. Kemudian dibebaskan untuk mengambil keputusan sendiri dan bertindak sesuai dengan keputusan yang diambilnya itu. Seseorang yang berbuat sesuatu, dan ternyata membawa akibat melanggar norma atau aturan yang berlaku, tidak diberi sanksi atau hukuman. Dampak teknik permisif ini berupa kebingungan dan kebimbangan. Penyebabnya karena tidak tahu mana yang tidak dilarang dan mana yang dilarang. Atau bahkan menjadi takut, cemas, dan dapat juga menjadi agresif serta liar tanpa kendali.

3. Disiplin Demokratis

Pendekatan disiplin demokratis dilakukan dengan memberi penjelasan, diskusi dan penalaran untuk membantu anak memahami mengapa diharapkan mematuhi dan menaati peraturan yang ada. Teknik ini menekankan aspek edukatif bukan aspek hukuman. Sanksi dapat diberikan kepada yang menolak atau melanggar tata tertib. Akan tetapi, hukuman dimaksud sebagai upaya menyadarkan, mengoreksi dan mendidik.

Teknik disiplin demokratis berusaha mengembangkan disiplin yang muncul atas kesadaran diri sehingga siswa memiliki disiplin diri yang kuat dan mantap. Oleh karena itu, bagi yang berhasil mematuhi dan menaati disiplin, kepadanya diberikan pujian dan penghargaan. Dan dalam disiplin demokratis, kemandirian dan tanggung jawab dapat berkembang. Siswa patuh dan taat karena didasari kesadaran dirinya. Mengikuti peraturan yang ada bukan karena terpaksa, melainkan atas kesadaran bahwa hal itu baik dan ada manfaat (Tu'u, 2004: 46).

Mereka mulai bertingkah laku berbeda, tetapi aturan dasar, asumsi dan nilai-nilainya sama. Hal yang dapat mempengaruhi dan membentuk disiplin (individu): mengikuti dan menaati aturan, kesadaran diri, alat pendidikan, hukuman. Keempat faktor ini 
merupakan faktor dominan yang mempengaruhi dan membentuk disiplin. Alasannya sebagai berikut:

1. Kesadaran diri sebagai pemahaman diri bahwa disiplin dianggap penting bagi kebaikan dan keberhasilan dirinya. Selain itu, kesadaran diri menjadi motif sangat kuat terwujudnya disiplin.

2. Pengikutan dan ketaatan sebagai langkah penerapan dan praktik atas peraturan-peraturan yang mengatur perilaku individunya. Hal ini sebagai kelanjutan dari adanya kesadaran diri yang dihasilkan oleh kemampuan dan kemauan diri yang kuat. Tekanan dari luar dirinya sebagai upaya mendorong, menekan dan memaksa agar disiplin diterapkan dalam diri seseorang sehingga peraturan-peraturan diikuti dan dipraktikkan.

3. Alat pendidikan untuk mempengaruhi, mengubah, membina dan membentuk perilaku yang sesuai dengan nilai-nilai yang ditentukan atau diajarkan.

4. Hukuman sebagai upaya menyadarkan, mengoreksi dan meluruskan yang salah sehingga orang kembali pada perilaku yang sesuai dengan harapan.

Selain keempat faktor tersebut, masih ada beberapa faktor lain lagi yang dapat berpengaruh pada pembentukan disiplin individu, antara lain: teladan, lingkungan berdisiplin, dan latihan berdisiplin (Tu'u, 2004: 49). Pendapat Soegeng Prijodarminto (1994: 23) tentang pembentukan disiplin, terjadi karena alasan berikut ini:

1. Disiplin akan tumbuh dan dapat dibina, melalui latihan, pendidikan, penanaman kebiasaan dan keteladanan. Pembinaan itu dimulai dari lingkungan keluarga sejak kanakkanak.

2. Disiplin dapat ditanam mulai dari tiap-tiap individu dari unit paling kecil, organisasi atau kelompok.

3. Disiplin diproses melalui pembinaan sejak dini, sejak usia muda, dimulai dari keluarga dan pendidikan.

4. Disiplin lebih mudah ditegakkan bila muncul dari kesadaran diri.

5. Disiplin dapat dicontohkan oleh atasan kepada bawahan. 
Bohar Soeharto sebagaimana dikutip oleh Tu'u (2004: 51) menyebutkan sebelas konsep dan prinsip-prinsip disiplin efektif yang perlu diperhatikan oleh para pembina, guru, instruktur dalam melatih, mempengaruhi dan membentuk disiplin terhadap para binaannya. Kesebelas konsep itu, sebagai berikut:

1. Suatu disiplin yang efektif akan berusaha memperkembangkan pengarahan diri secara maksimal.

2. Disiplin yang efektif didasarkan pada kebebasan dan keadilan.

3. Disiplin yang efektif akan membantu untuk mengenal diri lebih baik sebagai individu yang unik dan mandiri.

4. Disiplin yang efektif akan membangun konsep diri, yakni sebagai individu yang bermartabat dan perlu dihormati.

5. Disiplin yang efektif akan membantu untuk mengubah persepsinya terhadap situasi tertentu.

6. Disiplin yang efektif menggunakan kontrol secara bijak/ terbatas.

7. Disiplin yang efektif akan meningkatkan kesiapan individu untuk pengarahan diri lebih lanjut.

8. Disiplin efektif harus tertuju pada yang berkemauan untuk melaksanakan sesuatu tanpa paksaan.

9. Disiplin yang efektif pada dasarnya menetap.

10. Disiplin yang efektif jarang menggunakan hukuman sebagai cara untuk menakut-nakuti.

11. Disiplin yang efektif tidak menggunakan kutukan, tuduhan atau penyesalan.

Pelanggaran disiplin menurut pengalaman dan pengamatan Tu'u (2004: 53), dapat terjadi karena tujuh hal berikut ini:

1. Disiplin sekolah yang kurang direncanakan dengan baik dan mantap.

2. Perencanaan yang baik, tetapi implementasinya kurang baik dan kurang dimonitor oleh kepala sekolah.

3. Penerapan disiplin yang tidak konsisten dan tidak konsekuen.

4. Kebijakan kepala sekolah yang belum memprioritaskan peningkatan dan pemantapan disiplin sekolah.

5. Kurang kerja sama dan dukungan guru-guru dalam perencanaan dan implementasi disiplin sekolah. 
Siti Haryuni

6. Kurangnya dukungan dan partisipasi orang tua dalam menangani disiplin sekolah, secara khusus siswa yang bermasalah.

7. Siswa di sekolah tersebut banyak yang berasal dari siswa yang bermasalah dalam disiplin diri. Mereka ini cenderung melanggar dan mengabaikan tata tertib sekolah.

Kegiatan pengembangan diri dilakukan melalui kegiatan pelayanan konseling yang berkenaan dengan masalah diri pribadi dan kehidupan social, belajar dan pengembangan karir siswa (Retnanto, 2009: 70). Dalam buku Manajemen Kelas, Maman Rachman membagi ke dalam tiga kelompok penyebab munculnya pelanggaran disiplin sekolah:

1. Pelanggaran disiplin yang timbul oleh guru antara lain:

b. Aktivitas yang kurang tepat.

c. Kata-kata guru yang menyindir dan menyakitkan.

d. Kata-kata guru yang tidak sesuai dengan perbuatannya.

e. Rasa ingin ditakuti dan disegani.

f. Kurang dapat mengendalikan diri.

g. Suka mempergunjingkan siswanya.

h. Dalam pembelajaran memakai metode yang tidak variatif sehingga kelas membosankan.

i. Gagal menjelaskan pelajaran dengan menarik perhatian.

j. Memberi tugas terlalu banyak dan berat.

k. Kurang tegas dan kurang berwibawa sehingga kelas ribut dan tidak mampu menguasai.

2. Pelanggaran disiplin yang ditimbulkan oleh siswa antara lain:

a. Siswa yang suka berbuat aneh untuk menarik perhatian.

b. Siswa yang berasal dari keluarga disharmonis.

c. Siswa yang kurang istirahat di rumah sehingga mengantuk di sekolah.

d. Siswa yang kurang membaca dan belajar serta tidak mengerjakan tugas-tugas guru.

e. Siswa yang pasif, potensi rendah, lalu datang ke sekolah tanpa persiapan diri.

f. Siswa yang suka melanggar tata tertib sekolah. 
g. Siswa yang pesimis atau putus asa terhadap keadaan lingkungan dan prestasinya.

h. Siswa yang datang ke sekolah dengan terpaksa.

i. Hubungan antara siswa yang kurang harmonis, adanya konflik antara kelompok.

j. Adanya kelompok-kelompok eksklusif di sekolah.

Sedangkan bentuk-bentuk pelanggaran disiplin siswa yang kerap kali terjadi antara lain: bolos, tidak mengerjakan tugas dari guru, mengganggu kelas yang sedang belajar, menyontek, tidak memperhatikan pelajaran yang sedang dijelaskan oleh guru, berbicara dengan teman sebelahnya saat pelajaran berlangsung, terlambat hadir ke sekolah, terlibat dalam penggunaan obat terlarang dan perkelahian atau tawuran.

3. Pelanggaran disiplin yang timbul oleh lingkungan antara lain:

a. Kelas yang membosankan.

b. Perasaan kecewa karena sekolah bertindak kurang adil dalam penerapan disiplin dan hukuman.

c. Perencanaan dan implementasi disiplin yang kurang baik.

d. Keluarga yang sibuk dan kurang memperhatikan anakanaknya, serta banyak problem.

e. Keluarga yang kurang mendukung penerapan disiplin sekolah.

f. Lingkungan sekolah dekat dengan pusat keramaian (pasar, pertokoan, pabrik, bengkel, rumah sakit).

g. Manajemen sekolah yang kurang baik.

h. Lingkungan bergaul siswa yang kurang baik (Tu'u, 2004: $55)$.

Disiplin individu menjadi prasyarat terbentuknya kepribadian yang unggul dan sukses. Disiplin sekolah menjadi prasyarat terbentuknya lingkungan pendidikan yang kondusif bagi kegiatan dan proses pendidikan. Oleh karena itu, kepala sekolah, guru-guru dan orang tua perlu terlibat dan bertanggung jawab membangun disiplin siswa dan disiplin sekolah. Penanggulangan disiplin:

1. Adanya tata tertib, yang sangat bermanfaat untuk membiasakannya dengan standar perilaku yang sama dan 
Siti Haryuni

diterima oleh individu lain dalam ruang lingkupnya.

2. Konsisten dan konsekuen. Soegeng mengatakan, "Dalam menegakkan disiplin bukanlah ancaman atau kekerasan yang diutamakan. Yang diperlukan adalah ketegasan dan keteguhan di dalam melaksanakan peraturan. Hal itu merupakan modal utama dan syarat mutlak untuk mewujudkan disiplin”.

3. Hukuman yang bertujuan mencegah tindakan yang tidak baik.

4. Kemitraan dengan orangtua.

Penanggulangan masalah disiplin yang terjadi di sekolah menurut Singgih Gunarsa yang dikutip dalam Tu'u (2004: 57) dapat dilakukan melalui:

1. Tahapan preventif. Lebih pada usaha mendorong siswa melaksanakan tata tertib sekolah.

2. Tahapan represif. Sudah berurusan dengan siswa yang melanggar tata tertib sekolah. Siswa-siswa ini ditolong agar tidak melanggar lebih jauh lagi, dengan jalan nasihat, peringatan atau sanksi disiplin.

3. Tahapan kuratif. Upaya pembinaan dan pendampingan siswa yang melanggar tata tertib dan sudah diberi sanksi disiplin. Upaya tersebut merupakan langkah pemulihan, memperbaiki, meluruskan, menyembuhkan perilaku yang salah dan tidak baik.

\section{Simpulan}

Bimbingan dan konseling pendidikan adalah kegiatan atau proses bimbingan dan konseling yang diberikan kepada individu dalam kegiatan belajar atau pendidikannya agar selaras dengan tujuan pendidikan. Penekanan bimbingan pendidikan adalah preventif, yaitu mencegah munculnya problem dalam kegiatan pendidikan seseorang dengan senantiasa memelihara kondisi yang baik agar tetap atau lebih baik. Dan penekanan konseling adalah kuratif, yaitu bantuan pemecahan masalah-masalah yang berkaitan dengan pendidikan seseorang.

Peranan bimbingan konseling pendidikan dalam membentuk kedisiplinan adalah mengikuti dan menaati aturan, kesadaran diri, alat pendidikan, hukuman. Karena: 
1. Kesadaran diri sebagai pemahaman diri bahwa disiplin dianggap penting bagi kebaikan dan keberhasilan dirinya. Selain itu, kesadaran diri menjadi motif sangat kuat terwujudnya disiplin.

2. Pengikutan dan ketaatan sebagai langkah penerapan dan praktik atas peraturan-peraturan yang mengatur perilaku individunya. Hal ini sebagai kelanjutan dari adanya kesadaran diri yang dihasilkan oleh kemampuan dan kemauan diri yang kuat. Tekanan dari luar dirinya sebagai upaya mendorong, menekan dan memaksa agar disiplin diterapkan dalam diri seseorang sehingga peraturan-peraturan diikuti dan dipraktikkan.

3. Alat pendidikan untuk mempengaruhi, mengubah, membina dan membentuk perilaku yang sesuai dengan nilai-nilai yang ditentukan atau diajarkan.

4. Hukuman sebagai upaya menyadarkan, mengoreksi dan meluruskan yang salah sehingga orang kembali pada perilaku yang sesuai dengan harapan.

5. Teladan, lingkungan berdisiplin, dan latihan berdisiplin.

Sebagai seorang pembimbing konseling pendidikan (melalui layanan pengembangan diri) dalam usaha membentuk kedisiplinan perlu memperhatihan hal-hal sebagai berikut:

1. Suatu disiplin yang efektif akan berusaha memperkembangkan pengarahan diri secara maksimal.

2. Disiplin yang efektif didasarkan pada kebebasan dan keadilan.

3. Disiplin yang efektif akan membantu untuk mengenal diri lebih baik sebagai individu yang unik dan mandiri.

4. Disiplin yang efektif akan membangun konsep diri, yakni sebagai individu yang bermartabat dan perlu dihormati.

5. Disiplin yang efektif akan membantu untuk mengubah persepsinya terhadap situasi tertentu.

6. Disiplin yang efektif menggunakan kontrol secara bijak/ terbatas.

7. Disiplin yang efektif akan meningkatkan kesiapan individu untuk pengarahan diri lebih lanjut. 
Siti Haryuni

8. Disiplin efektif harus tertuju pada yang berkemauan untuk melaksanakan sesuatu tanpa paksaan.

9. Disiplin yang efektif pada dasarnya menetap.

10. Disiplin yang efektif jarang menggunakan hukuman sebagai cara untuk menakut-nakuti.

11. Disiplin yang efektif tidak menggunakan kutukan, tuduhan atau penyesalan.

Sehingga pengembangan diri bertujuan memberikan kesempatan pada diri siswa untuk mengembangkan dan mengekspresikan diri sesuai dengan kebutuhan, bakat dan minat dalam mewujudkan budaya disiplin sejak dini pada setiap diri siswa. 
Penerapan Bimbingan |Konseling Pendidikan

\section{DAFTAR PUSTAKA}

Djojonegoro, Wardiman.1996. Visi dan Strategi Pembangunan

Pendidikan Untuk Tahun 2020 Tuntutan Terhadap Kualitas. Bandung: Mimbar Pendidikan IKIP

Hamdani. 2012. Bimbingan dan Penyuluhan. Bandung: Pustaka Setia. Hasibuan, J.J. dkk. (1988). Proses Belajar Mengajar. Bandung: Remaja Karya.

Indrakusuma, A.D. (1973). Pengantar Ilmu Pengetahuan. Malang: Fakultas Ilmu Pendidikan IKIP Malang.

Najati, Muhammad Utsman. 2005. Psikologi Nabi: Membangun Pesona Diri dengan Ajaran-ajaran Nabi SAW. Bandung: Pustaka Hidayah.

Prijodarminto, Soegeng. 1994. Disiplin Kiat Menuju Sukses. Jakarta: Pradnya Paramita

Rachman, Maman.1999. Manajemen Kelas. Jakarta: Depdiknas

Retnanto, Agus. 2009. Bimbingan dan Konseling. STAIN Kudus: Daros.

Shochib, M. 1998. Pola Asuh Orang tua: Untuk Membantu Anak Mengembangkan Disiplin Diri. Jakarta: Rineka Cipta.

Sukardi, D. K. 2000. Pengantar Pelaksanaan Program Bimbingan dan Konseling. Jakarta: Rineka Cipta.

Suwarno. (1992). Pengantar Ilmu Pendidikan. Jakrta: PT. Rineka Cipta.

Tu’u, Tulus. 2004. Peran Disiplin Pada Perilaku dan Prestasi Siswa. Jakarta: Gramedia Widiasarana Indonesia.

Wijanarko, Jarot. 2005. Mendidik anak: untuk meningkatkan kecerdasan emosional. Jakarta: Gramedia Pustaka Utama. 
Siti Haryuni

halaman ini bukan sengaja dikosongkan 